Provided for non-commercial research and education use. Not for reproduction, distribution or commercial use.

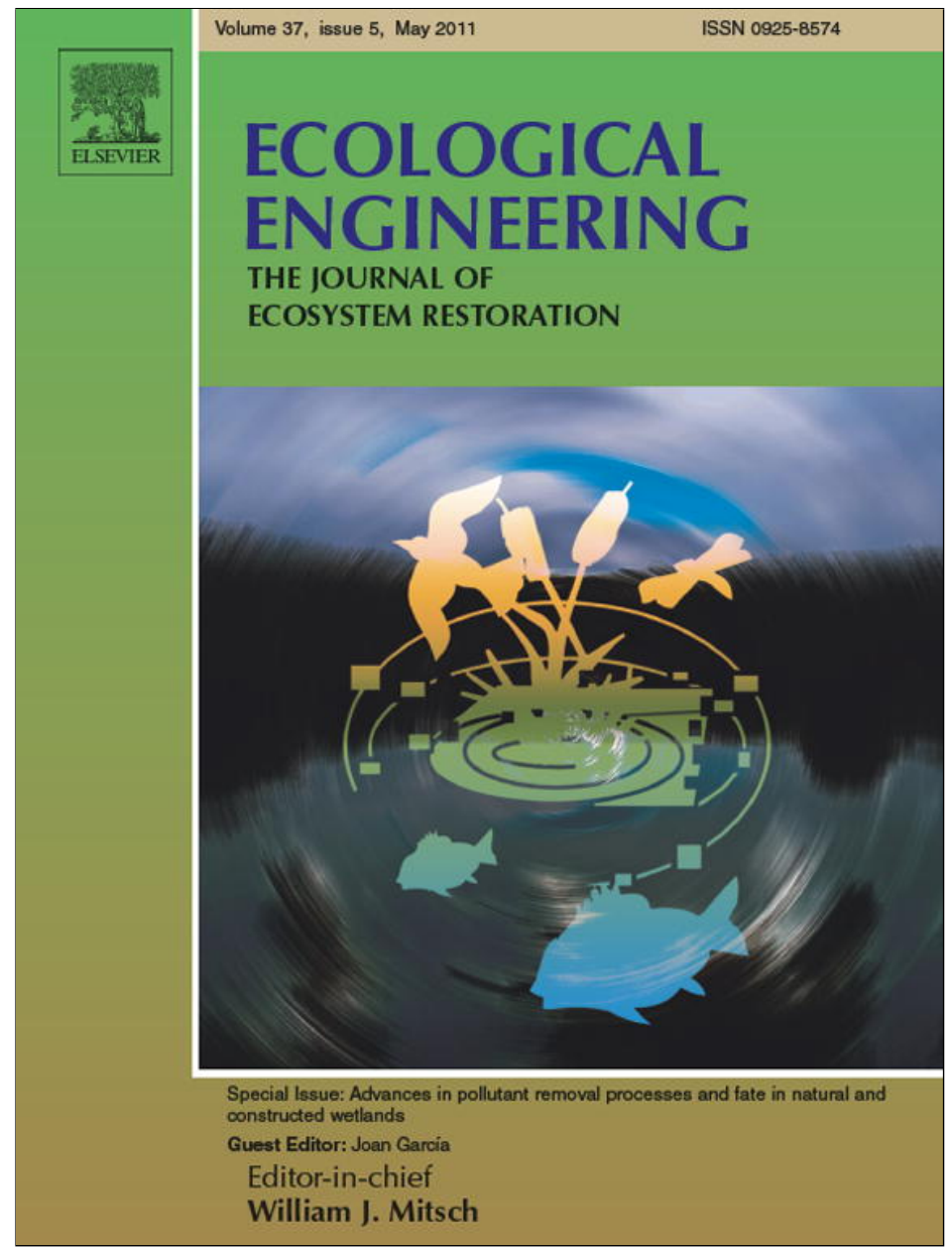

This article appeared in a journal published by Elsevier. The attached copy is furnished to the author for internal non-commercial research and education use, including for instruction at the authors institution and sharing with colleagues.

Other uses, including reproduction and distribution, or selling or licensing copies, or posting to personal, institutional or third party websites are prohibited.

In most cases authors are permitted to post their version of the article (e.g. in Word or Tex form) to their personal website or institutional repository. Authors requiring further information regarding Elsevier's archiving and manuscript policies are encouraged to visit:

http://www.elsevier.com/copyright 


\title{
The flower and the butterfly constructed wetland system at Koh Phi Phi-System design and lessons learned during implementation and operation
}

\author{
Hans Brix ${ }^{\mathrm{a}, *}$, Thammarat Koottatep ${ }^{\mathrm{b}}$, Ole Fryd ${ }^{\mathrm{c}}$, Carsten H. Laugesen ${ }^{\mathrm{d}}$ \\ a Aarhus University, Department of Biological Sciences, Ole Worms Allé 1, DK-8000 Århus, Denmark \\ ${ }^{\mathrm{b}}$ Asian Institute of Technology, School of Environment, Resources and Development, Klong Luang, Pathumthani, Thailand \\ ${ }^{\mathrm{c}}$ University of Copenhagen, Danish Centre for Forest, Landscape \& Planning, Frederiksberg, Denmark \\ d Embassy of Denmark, Pretoria, South Africa
}

\section{A R T I C L E I N F O}

\section{Article history:}

Received 16 January 2010

Received in revised form 8 June 2010

Accepted 9 June 2010

Available online 23 July 2010

\section{Keywords}

Canna

Clogging

Ecotechnology

Heliconia

Papyrus

Tsunami

Vertical flow

Wastewater

\begin{abstract}
A B S T R A C T
In 2007, a constructed wetland system was implemented on the tourist island of Koh Phi Phi in Southern Thailand. This paper presents the process of planning, designing and implementing the system and discusses the performance and operational issues 3 years after implementation. The system is an international lighthouse project showing the potential for aesthetical integration of constructed wetland systems in the built environment. The system comprises a wastewater collection system for the main business and hotel area of the island, a pumping station and a pressure pipe system to the treatment facility, a multi-stage constructed wetland system, and a system for reuse of treated wastewater. The treatment chains consist of vertical-flow, horizontal subsurface flow and free water surface flow units. Because the treatment system is located at the centre of the island, surrounded by resorts, restaurants and shops, the systems are designed with terrains as scenic landscaping. The wastewater is treated to meet the Thai effluent standards for total suspended solids and nitrogen, but because of inadequate pre-treatment and removal of oil and grease prior to the system, the standards for oil and grease and BOD are not met. A number of challenges during construction and operation have caused problems with clogging of the vertical flow constructed wetlands and given rise to odour problems. Safeguards were prepared, but not effectively activated, mainly because no key-person or key-authority took responsibility for managing the system.
\end{abstract}

(c) 2010 Elsevier B.V. All rights reserved.

\section{Introduction}

In January 2005, the Danish Government gave a tsunami relief grant to Thailand to re-establish the wastewater management services at Koh Phi Phi, a mountainous island located in the archipelago of the Andaman Sea on the west coast of Southern Thailand (Brix et al., 2007). The tsunami had destroyed hotels, shops, utility networks and other infrastructure on the island and killed hundreds of people (Papadopoulos et al., 2006; Kouchi and Yamazaki, 2007; Rigg et al., 2008). Koh Phi Phi Island consists of two mountains connected by a narrow sand strip, about $1.5 \mathrm{~km}$ long and $200 \mathrm{~m}$ wide, creating two U-shaped lagoons and making the contour of the island similar to the shape of a butterfly. The mountainous parts of the island are preserved as a part of a national park, and nearly all the commercial tourist businesses are located on private land on the narrow sand strip. More than one million tourists

\footnotetext{
* Corresponding author. Tel.: +45 89424714; fax: +45 89424747.

E-mail address: hans.brix@biology.au.dk (H. Brix).
}

visit the island every year, and the development of an appropriate wastewater management system for Koh Phi Phi was therefore a great challenge.

\section{Planning context}

Koh Phi Phi has a history of bad experiences with the involvement of government authorities, consultants and contractors. A centralized wastewater treatment system using waste stabilization ponds had previously been planned and implemented by the central government, but it never went into proper operation, as the collection system had been implemented with at negative slope and all wastewater accumulated at the lowest point somewhere in the centre of the commercial district. As a consequence, the local authority had implemented a by-law prohibiting residents from connecting to the collection system (Laugesen et al., 2010). In addition, no training of local staff had occurred, and had the system come into operation, it would probably have been too expensive for the local administration to operate and maintain. 


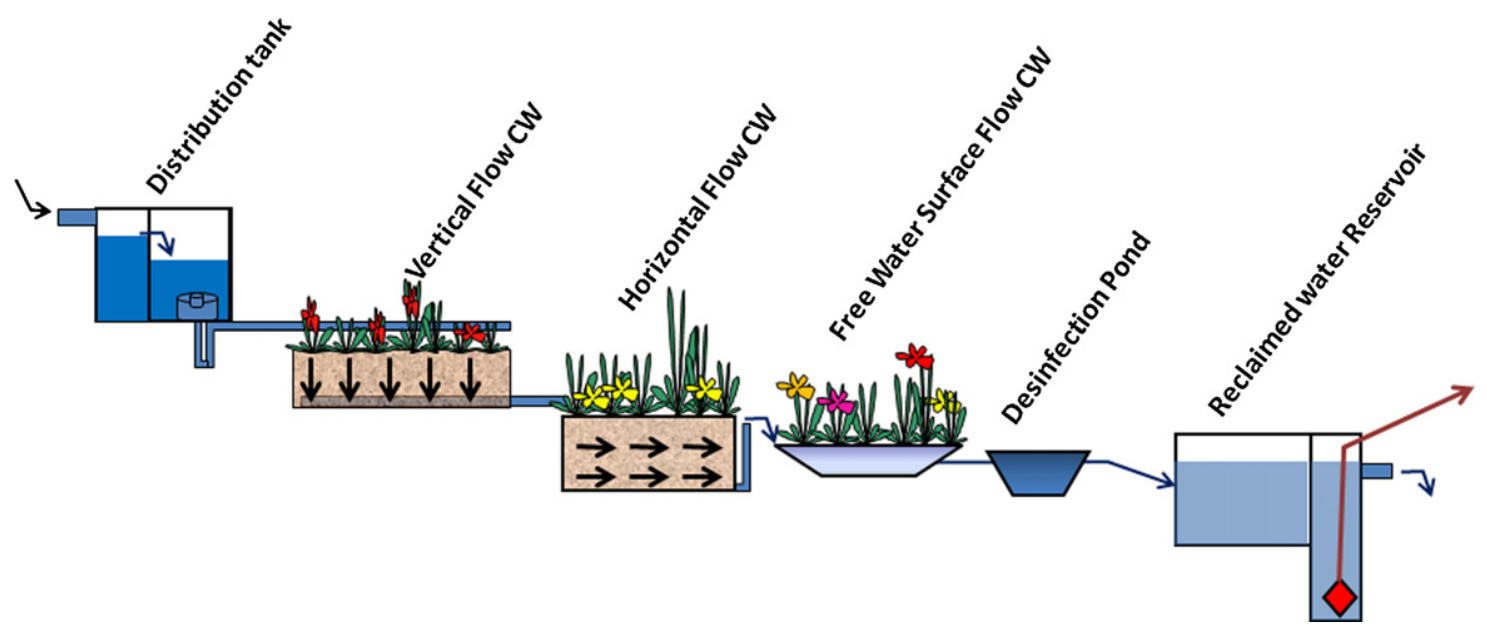

Fig. 1. Concept for the treatment system as a series of vertical flow, horizontal flow and free water surface flow constructed wetlands followed by a pond and reservoir.

Koh Phi Phi experiences the typical island issues of scarcity, i.e. water scarcity, land scarcity, energy scarcity. The freshwater resource is limited and expensive. As there is no power line connecting the island to the grid on the main land all energy are supplied by diesel generators, which is a noisy and polluting power source. Most of the island is a national park and the narrow sand strip covering an area of 30 ha is historically divided among private landowners. A $6000 \mathrm{~m}^{2}$ plot is the only land owned by the municipality, which challenges the scope of providing public spaces for residents and visitors, such as parks and sports facilities. Other issues of scarcity include professional and economic capacity. Of the approximately 3000 permanent residents on the island it can be difficult to find people capable of operating an advanced wastewater management system. In addition, for long term sustainability, the salary, operations and maintenance costs must be minimal to fit the economy the local authority.

The more than 1 million tourists visiting the island every year expect to see a tropical paradise with clear water in the lagoons, white sandy beaches and lush vegetation. They do not expect dense algae populations in the sea, the smell of wastewater, the noise of generators or concrete structures resembling the city they try to escape from. The municipal land plot available for the treatment system is located alongside one of the island's main traffic routes, which all visitors pass while strolling the island. This strengthens the need of an odour-free and aesthetically appealing facility fitting the image of a tropical island paradise.

The limited land, water and energy resources, the lessons from the previously installed wastewater management system, the local economy and professional capacity and desires of the tourists and tourism industry formed the framing premises and implied high contextual demands for the system to be developed.

\section{Design process}

The residents and the mayor in particular had learned the lessons from the previous failed wastewater management system on the island. As a consequence, the development of a new system after the tsunami necessitated significant involvement of the local stakeholders in all phases of the project. Hence, the mayor, the community leader, business leaders, and the local and the regional authorities were all involved. It was the ambition of the design team to develop as many win-win situations and as many interdependent relationships among stakeholders as possible in order to enhance long term sustainability of the project. Public hearings and a vote system on system requirements and the physical layout of the system were held along the way in the process.

High priority in the project was to secure sustainability through the fitting of the wastewater management system into the local settings and by applying low-cost, robust and appropriate technologies. The approach of the rehabilitation project was therefore to focus on constructed wetland systems, which are known to fulfil many of these requirements as they are generally reliant and costefficient (Brix and Schierup, 1989; Koottatep et al., 2005; Vymazal et al., 2006; Kadlec and Wallace, 2009). In addition, constructed wetlands can facilitate biological, aesthetical and social synergies in the built environment (Brix, 1999; Brix et al., 2007; Zurita et al., 2009; Konnerup et al., 2009; Dreiseitl and Grau, 2009).

The initial design criteria were a capacity of $400 \mathrm{~m}^{3} \mathrm{~d}^{-1}$ and influent levels of BOD (Biochemical Oxygen Demand) at $100 \mathrm{mg} \mathrm{L}^{-1}$ and TKN (Total Kjeldahl Nitrogen) at $10 \mathrm{mg} \mathrm{L}^{-1}$. To respond to the experienced water scarcity on the island the treated wastewater should be re-useable as a secondary water resource. Given the framing premise of land scarcity, vertical flow constructed wetlands were quickly agreed on as a main component of the system because of their high treatment capacity and relatively smaller footprint (Brix and Arias, 2005; Cooper, 2005; Kantawanichkul et al., 2009). It was decided to concentrate on a system with three parallel lines of vertical flow, horizontal flow and free water surface flow constructed wetlands followed by a pond and a reservoir (Fig. 1).The design process explored a number of alternative layouts (Fig. 2).Some were optimized for a plug-flow in the wetland system, others highlighted the even distribution onto the vertical flow constructed wetland, and yet others had special artistic designs based on the contours of the Phi Phi Islands as seen from the air. The limited availability of public land and the potential of developing the wastewater treatment system into a multi-functional park mutually addressing the need for recreational areas, sports grounds, tropical plants and public open spaces came to play an important role in the design process. As the creative process progressed, the concept of a butterfly sitting on a flower evolved.

\section{Final design - the flower and the butterfly}

The treatment facility is designed to resemble a butterfly sitting on a flower, with a symbolic reference to the butterfly-shaped contour of Koh Phi Phi (Fig. 3). The relationship between the flower as a living organism and the butterfly as a carrier of pollen also symbolizes the new beginning, the growth and bloom of the flower, the community, and the island in the aftermath of the tsunami. 

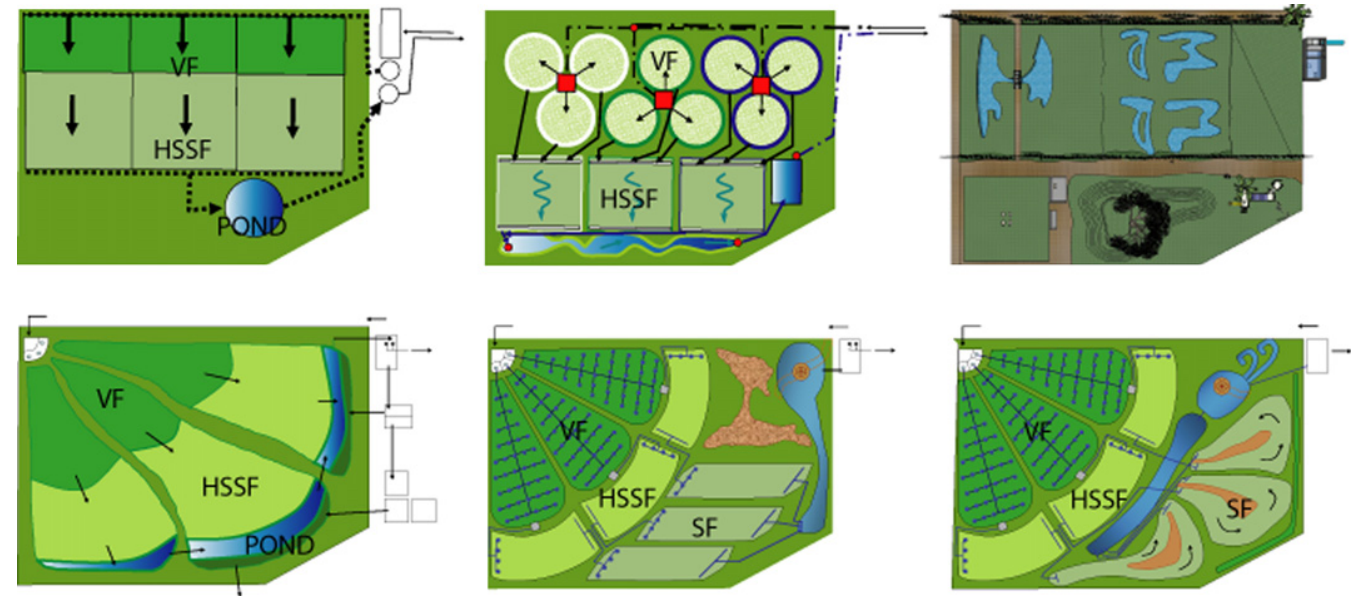

Fig. 2. Examples of layouts developed and discussed in the design process: (from top left) (i) conceptual engineering design with square wetland beds, (ii) circular batchloaded circular vertical flow beds optimised for water distribution, (iii) artistic landscape design with contours of the Phi Phi Islands, (iv and v), combined functional and landscaped designs, and (vi) the final 'Flower and Butterfly' wetland system. VF, vertical flow beds; HSSF, horizontal subsurface flow beds; SF, surface flow beds (from Laugesen et al., 2010).

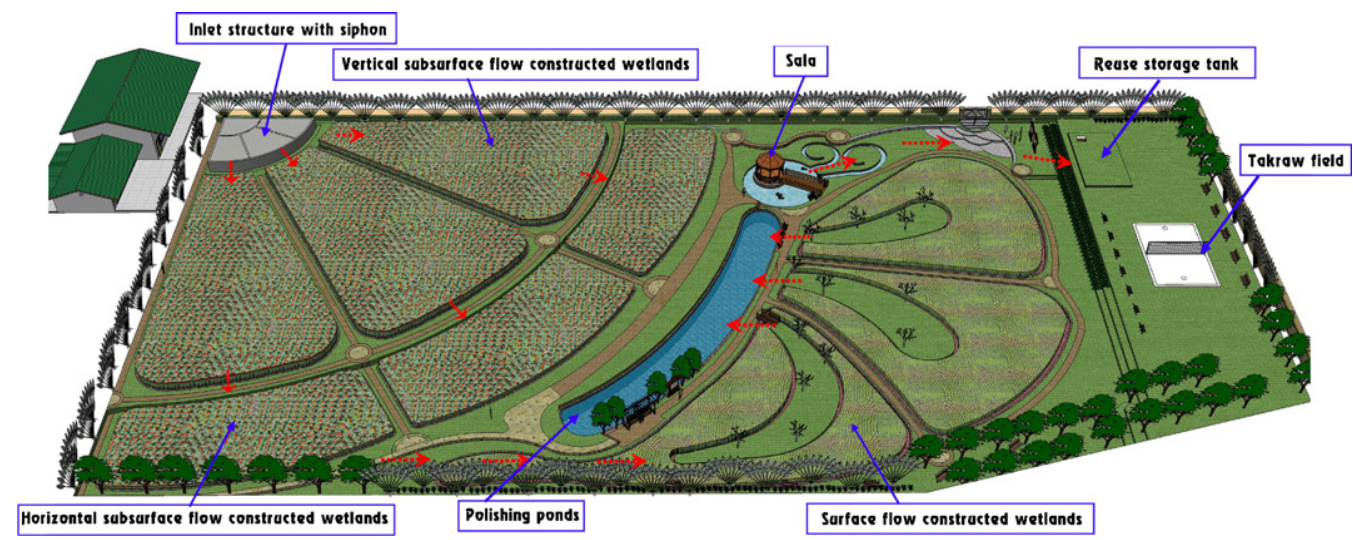

Fig. 3. Artist drawing of the 'Flower and Butterfly' wastewater management system. Wastewater enter the system at the distribution tank with three elevated siphons (the center of the flower), which distribute the wastewater in intervals to three vertical subsurface-flow wetlands (the first petal of the flower). The flow is then directed via pipelines to three horizontal subsurface flow wetland cells (second petal of the flower). From there, the wastewater flow to three surface-flow wetlands (the wings of the butterfly), and then enter the polishing ponds (the butterfly body), the last stage of treatment through which the effluent pass before it is stored for irrigation purposes (from Laugesen et al., 2010).

The wastewater management system is designed as a recovery based closed-loop system where wastewater is collected, treated and reused in an integrated system. The system is dimensioned to treat up to $400 \mathrm{~m}^{3} \mathrm{~d}^{-1}$ of mixed black and grey water and aims to be a 'friendly neighbour', where odour control, aesthetics and social involvement is equally important to the treatment performance.

The wastewater management system comprises several components. The first treatment step is occurring in the individual septic tanks receiving blackwater from residential or commercial buildings in the serviced area. From there the wastewater enters a partly separate collection system, which connects to a pumping station equipped with an odour control unit. To minimise costs of operation and to promote renewable energy the pumps are solar powered. The wastewater is pumped to three elevated siphons (located in the centre of the flower), which distribute the wastewater in intervals to three vertical subsurface-flow wetlands (the first petal of the flower, area: $2,300 \mathrm{~m}^{2}$, depth: $0.70 \mathrm{~m}$, gravel size: $\emptyset 10,25$ and $40 \mathrm{~mm}$ (from top to bottom), planted the ornamental flowers Canna and Heliconia). The main treatment processes take place in these vertical-flow cells. The flow is then directed to three horizontal-flow wetland cells (second petal of the flower, area: $750 \mathrm{~m}^{2}$, depth: $0.60 \mathrm{~m}$, gravel size: $\emptyset 25 \mathrm{~mm}$, planted with
Canna), and from there to three surface-flow wetlands (the wings of the butterfly, area: $750 \mathrm{~m}^{2}$, depth: $0.60 \mathrm{~m}$, planted with Papyrus), and finally to the polishing ponds (the butterfly body, area: $200 \mathrm{~m}^{2}$, depth: $0.70 \mathrm{~m}$ ). Treated effluent is stored in an underground reservoir for reuse (irrigation) purposes. The final design was presented at a public hearing, where all 150 delegates voted in favour of the proposal on behalf of the entire population of Koh Phi Phi, prior to project implementation.

\section{Implementation}

The municipality allocated the only piece of communal land on the island for the treatment system and a local landowner provided land for the pumping station. It was not legally possible to force households to connect to public wastewater collection systems. Consequently, it was decided to provide household connections as an integral part of the wastewater management system. This meant that the construction contract included service pipes and actual connection taps for households that needed and wanted to connect, and the installation of septic tanks and oil and grease traps for households, restaurants, and hotels that were willing to have them installed. 
The construction of the system was carried out by a local contractor with considerable working experience on the island. To promote the link to local suppliers and local pricing, and to ensure loyalty and mutual responsibility, the contractor hired members of the local community as advisors and middle managers in the construction phase. This also served to disseminate knowledge about the system and its' technical components into the local community.

For reasons of affordability and replicability the media in the vertical flow and horizontal flow constructed wetland cells should be locally available, and in order to minimize the risk of clogging it was decided to implement a pure gravel filter with three different sizes of crushed stone. Being on an island in a national park, 'locally' still meant that more than $3000 \mathrm{~m}^{3}$ of gravel had to be shipped to Koh Phi Phi from the mainland, located $40 \mathrm{~km}$ away.

Local and international consultants monitored the construction by site visits with approximately 2 weeks intervals; a full day journey from the central office in Bangkok including air, land and sea transport. In March 2006, about half way through the construction phase, it was identified that the contractor had mixed soil into the gravel filter medium, especially in the vertical flow units - maybe to facilitate the planting of flowers on top of the gravel filter, maybe to reduce material transportation costs. The contractor was immediately asked to remove the media in the gravel filters, cleanse the gravel and re-install the gravel as outlined in the design drawings and technical specifications. Subsequently, the frequency of monitoring the construction was increased. The wastewater management system was put into operation on the 14th of October 2006 (Fig. 4). The total cost of the system accounted to 28 million Thai baht (approximately $\$ 700,000$ USD in 2006).

\section{Safeguards}

The wastewater management system was not just built and then left to the municipality. It was anticipated that close follow-up and adjustments would be required, especially as not all stakeholders volunteered to have oil and grease traps installed on their private land during the construction phase. A number of post-construction safeguards were established to assist the municipality in operating and maintaining the system and to reduce the risk of system failure. Safeguards included:

- A performance bond of $10 \%$ of the construction cost, which enabled the municipality and the donor to require the contractor to rectify mistakes or omissions discovered within the first year after construction.

- A 3-year post-supervision contract signed with a local wastewater management expert to closely monitor and supervise the technical operation and maintenance tasks that would

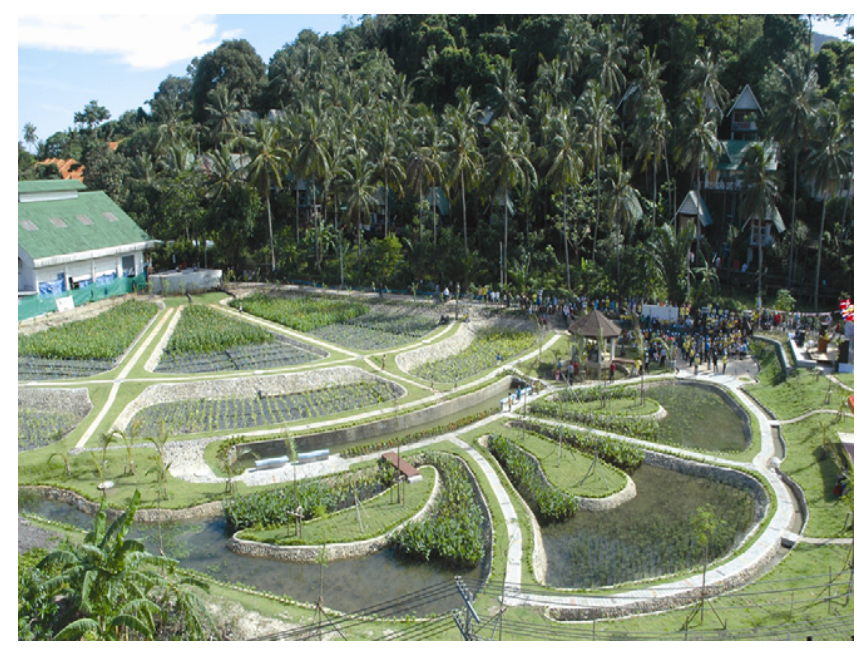

Fig. 4. Overview picture of the Flower and the Butterfly wastewater management system at Koh Phi Phi in October 2006 when the system was put in operation.

arise and inform the municipality and donor if immediate action was to be enacted to sustain the system.

- A 5-year budget covering operation and maintenance tasks was provided to the municipality with bi-yearly installments of 250,000 baht ( $\$ 6300$ USD) in order to provide time for the municipality to include the full costs in its normal budget and to make it possible for the donor to withhold budgets if necessary.

- The implementation of public relations activities informing about the importance of oil and grease traps and the collection system and a community-based committee responsible for the operational and financial aspects of the wastewater management system.

\section{Performance}

Concentrations of the influent and effluent at the constructed wetland wastewater treatment system at Koh Phi Phi have been monitored monthly from December 2006 to December 2008. All samples were analysed for $\mathrm{pH}$, total suspended solids (TSS), 5-day biochemical oxygen demand $\left(\mathrm{BOD}_{5}\right)$, total Kjeldahl nitrogen (TKN), nitrate nitrogen $\left(\mathrm{NO}_{3}-\mathrm{N}\right)$, total phosphorus (Total-P), oil and grease and faecal coliform bacteria in accordance with standard methods (APHA, 1998).

The results of the monitoring are provided in Table 1 . The composition of the influent wastewater resembles normal domestic sewage in industrialised temperate countries in terms of BOD and nutrient concentrations, but more concentrated than anticipated based on experiences from other areas of Thailand, where

Table 1

Average ( \pm standard deviation) inlet and outlet water quality for the wastewater management system at Koh Phi Phi during the period December 2006-December 2008. $n$, number of samples (monthly sampling).

\begin{tabular}{|c|c|c|c|c|c|}
\hline & \multicolumn{2}{|c|}{ Inlet } & \multicolumn{2}{|c|}{ Outlet } & \multirow{2}{*}{$\begin{array}{l}\text { Thai effluent } \\
\text { standards }\end{array}$} \\
\hline & $n$ & $\operatorname{Avg} \pm$ std & $\bar{n}$ & $\operatorname{Avg} \pm$ std & \\
\hline $\mathrm{pH}$ & 24 & $7.2 \pm 0.2$ & 24 & $7.7 \pm 0.3$ & $5.5-9.0$ \\
\hline TSS $\left(\mathrm{mg} \mathrm{L}^{-1}\right)$ & 24 & $160 \pm 65$ & 24 & $16 \pm 8$ & $<50$ \\
\hline $\mathrm{BOD}_{5}\left(\mathrm{mg} \mathrm{L}^{-1}\right)$ & 24 & $297 \pm 132$ & 24 & $25 \pm 9$ & $<20$ \\
\hline $\mathrm{TKN}\left(\mathrm{mg} \mathrm{L}^{-1}\right)$ & 24 & $54 \pm 23$ & 24 & $33 \pm 13$ & $<100$ \\
\hline $\mathrm{NO}_{3}-\mathrm{N}\left(\mathrm{mg} \mathrm{L}^{-1}\right)$ & 15 & $0.2 \pm 0.2$ & 15 & $0.1 \pm 0.1$ & - \\
\hline Total-P $\left(\mathrm{mg} \mathrm{L}^{-1}\right)$ & 8 & $8.4 \pm 3.1$ & 8 & $4.5 \pm 1.1$ & - \\
\hline Oil and grease $\left(\mathrm{mg} \mathrm{L}^{-1}\right)$ & 9 & $111 \pm 82$ & 9 & $11 \pm 13$ & $<5$ \\
\hline $\begin{array}{l}\text { Faecal Coliforms } \\
\quad(\mathrm{CFU} / 100 \mathrm{~mL})\end{array}$ & 11 & $3.9 \mathrm{E}+06 \pm 4.7 \mathrm{E}+06$ & 11 & $0.3 \mathrm{E}+06 \pm 0.5 \mathrm{E}+06$ & - \\
\hline Temperature $\left({ }^{\circ} \mathrm{C}\right)$ & 15 & $29.1 \pm 0.9$ & 11 & $29.1 \pm 1.0$ & - \\
\hline
\end{tabular}



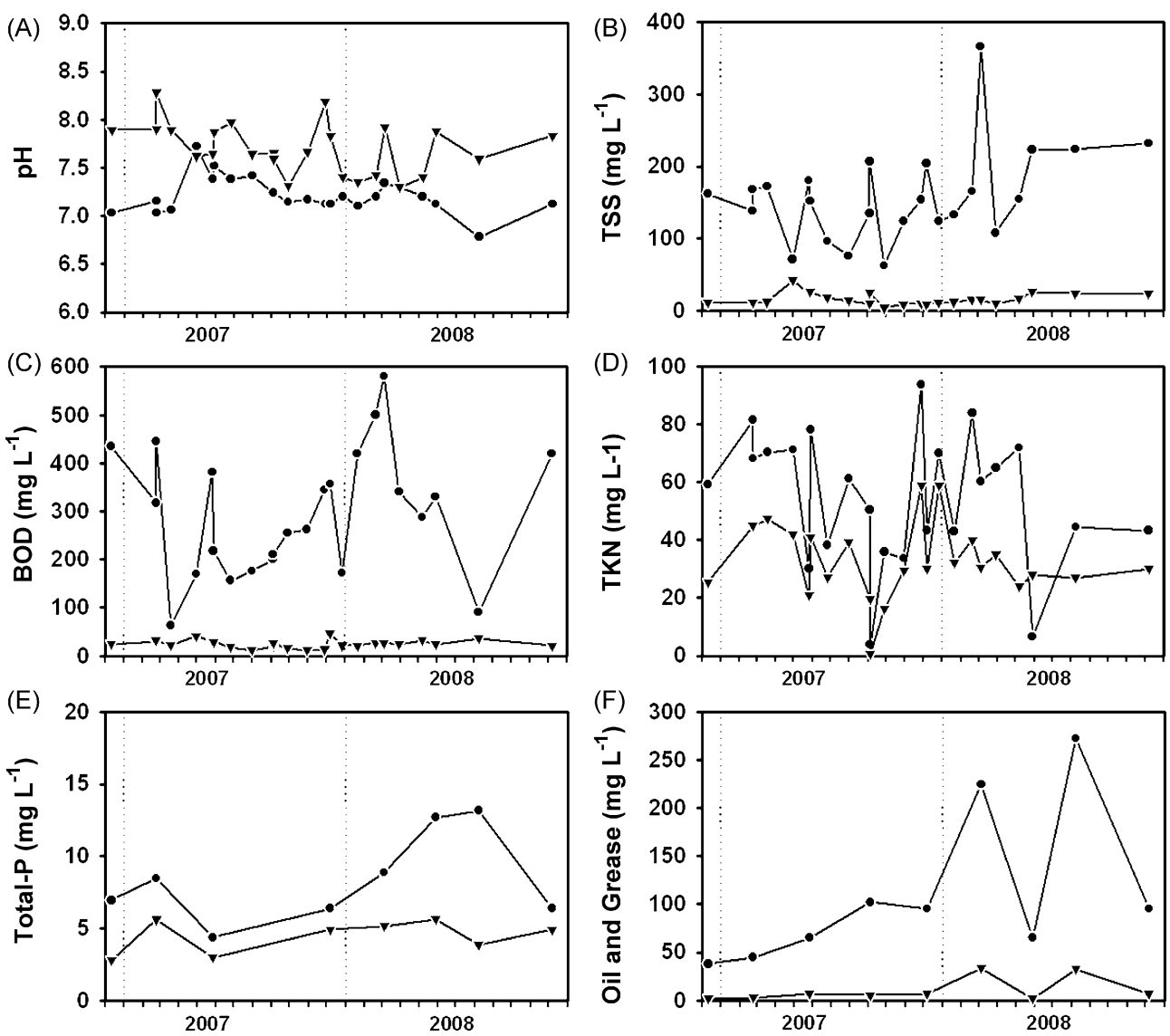

Fig. 5. Monitoring results of influent and effluent water quality of the wastewater management system at Koh Phi Phi. (A) pH, (B) total suspended solids, (C) biochemical oxygen demand, (D) total Kjeldahl nitrogen, (E) total phosphorus, and (F) oil and grease.

the domestic sewage is pre-treated prior to discharge into the sewer system (Laugesen et al., 2010). Particularly the contents of oil and grease and the concentrations of nitrogen were unexpectedly high. The effluent from the system was meeting the Thai effluent standards for $\mathrm{pH}$, TSS and TKN, but effluent BOD concentrations were slightly higher (average $25 \mathrm{mg} \mathrm{L}^{-1}$ ) than the $20 \mathrm{mg} \mathrm{L}^{-1}$ effluent standard. Also, the outlet concentrations of oil and grease were higher than the $5 \mathrm{mg} \mathrm{L}^{-1}$ requirement. The concentrations of faecal coliform bacteria were reduced by nearly 2 orders of magnitude, however variability in both inlet and outlet concentrations were high. The problems with high concentrations of oil and grease in effluent coincided with very high influent concentrations ( $>200 \mathrm{mg} \mathrm{L}^{-1}$ ) in 2008 (Fig. 5F) probably as a consequence of illegal connections to the wastewater collection systems and the lack of oil and grease traps at individual resident houses, restaurants, hotels and other businesses. As expected, the 1st stage vertical flow wetland units had a high capacity to remove BOD and TSS (Fig. 6A) despite the operational problems and the saturated conditions caused by the clogging by high loadings of sludge and grease (see next paragraph). However, the 1st stage vertical flow wetland units were also expected, because of the unsaturated flow, to be able to nitrify ammonium, but the nitrification
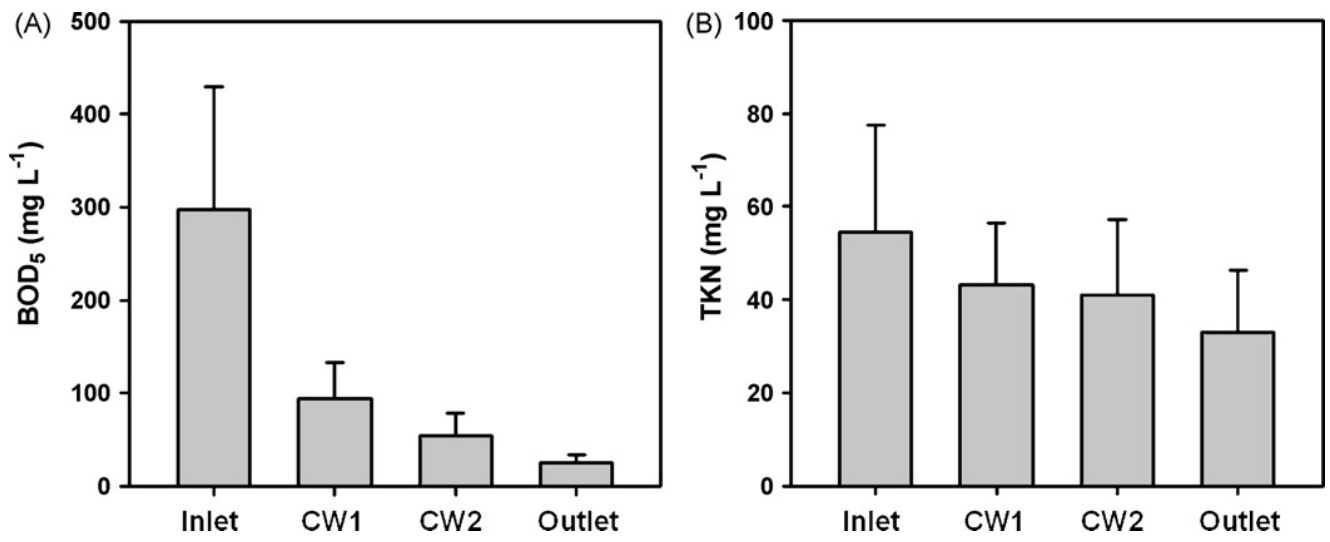

Fig. 6. Water quality profiles for (A) BOD and (B) TKN through the wastewater management system at Koh Phi Phi. Inlet=inlet to the 1 st stage vertical flow wetland; $\mathrm{CW} 1=$ outlet from the 1 st stage vertical flow wetland; $\mathrm{CW} 2=$ outlet from the horizontal subsurface flow wetland; outlet $=$ outlet from the system. 

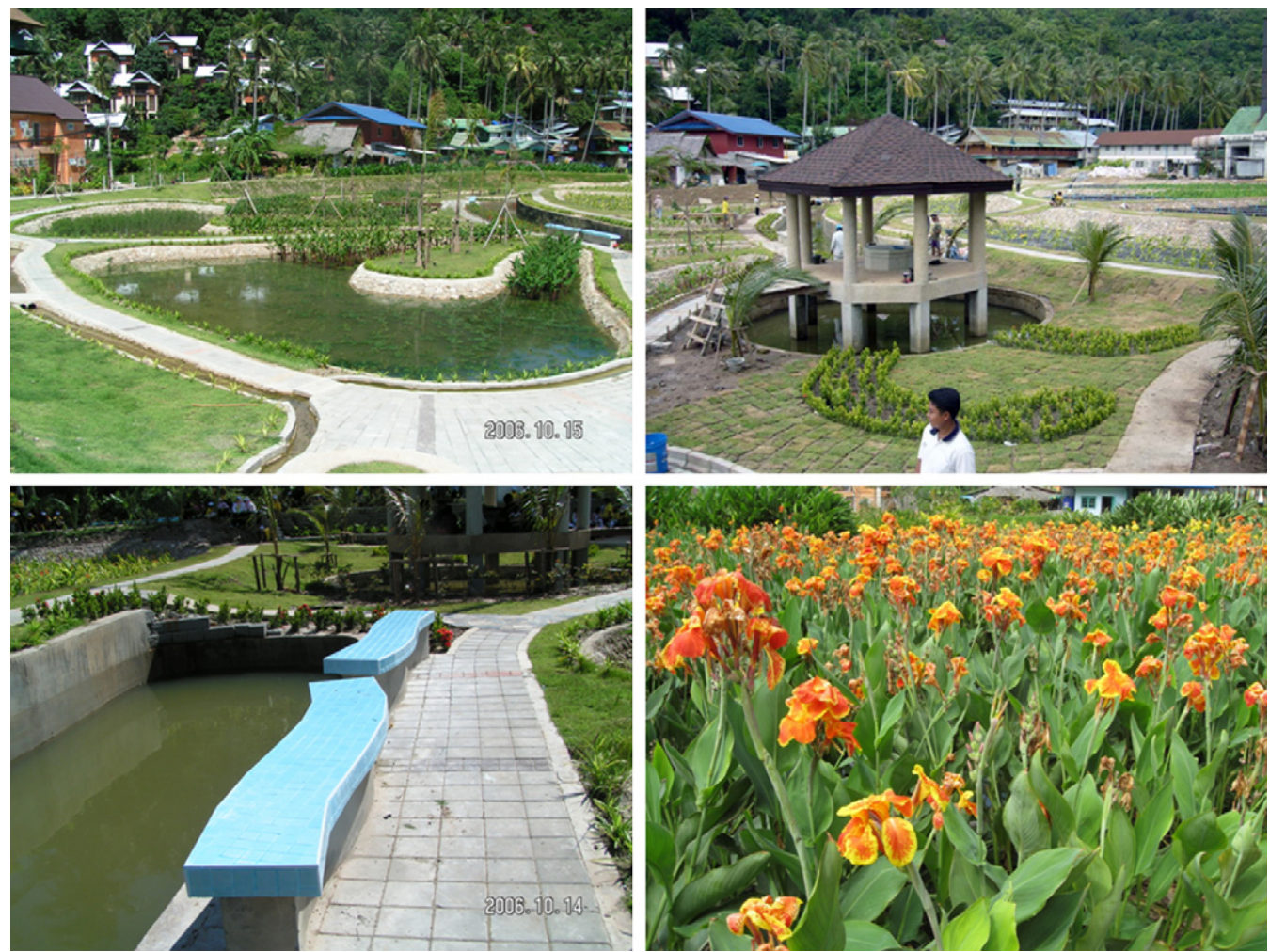

Fig. 7. The park like appearance of the Koh Phi Phi wastewater management system showing (from upper left to lower right): The free-water surface flow wetlands (the wing of the butterfly), the Sala with benches (head of butterfly), benches along the pond constituting the body of the butterfly, and luxurious growth and flowering of Canna lilies in the vertical flow beds.

activity was obviously low as judged by the low removal of TKN (Fig. 6B).

\section{Operational problems}

The plants in the constructed wetland system have developed very well, and overall the system from the distance has a very nice appearance due to the large number of blooming Canna and other lush green plants (Fig. 7). Still, it is only to be expected that wastewater management facilities during the first years of operation experience a number of operation and maintenance issues. Some of these originate from the construction works, some from the always-required adjustments and the run-in of the operation of the plant, especially a biological and innovative treatment facility as the one established on Koh Phi Phi.

On the technical side, it turned out not to be possible to install oil and grease traps in all restaurants either during or after construction, despite the offer of doing it free of charge. The lack of grease traps resulted in high levels of oil and grease in the collection system and in the treatment plant which increased the clogging of the gravel beds. Some major stakeholders did not allow implementation of separate sewers on their private land resulting in wastewater in some areas being collected in semiopen stormwater channels. This caused problems with dirt and floatables at the pumping station and the risk of raw wastewater reaching street level during heavy rain events. The influent proved more concentrated than expected causing high BOD loading rates at the treatment system. In addition, new and un-controlled connections resulting from 'pirating' and the rapid reconstruction and return of tourists after the tsunami created higher flow rates than the designed capacity. Despite the request for rectification during the construction phase, some soil remained in the gravel filter. Moreover, during the run-in of the system it was identified that the contractor had made a wrong packing of the filter gravel and that soil was located in the middle of the gravel layers in all three vertical flow constructed wetland cells. This observation with a remark of the increased risk of clogging was reported by the local expert to the municipality and donor for them to decide on actions to be taken, herein whether and how to activate the safeguards. The identified problems would not seriously impact the system if solutions were implemented quickly and effectively. However, nobody reacted upon the warnings.

Though the operators tried to remediate the system as best they could, the problems were not satisfactorily solved. The residents and business owners seemed generally satisfied with the system as they got rid of the wastewater. The community-based committee, the municipality and the mayor remained passive and did not actively take responsibility for management and problem solving. No public relations support was provided to increase awareness of the importance of the collection system and the oil and grease traps. The donor did not effectively activate the safeguards, but seemed more focused on placing a responsibility for the malfunction of the system. The performance bond safeguard was not activated within a year after commencement to make the contractor rectify the reported issues. It seems that the municipality did not take charge (Koottatep et al., 2009) and that there was no key-person to bring issues to a solution.

As always, the lack of action stems from a complex mix of reasons. Although financial and technical tools were in place, time and energy were wasted on reports and discussions without actions to solve the observed and manageable operation issues. Meanwhile, smell problems increased and the challenge of rectifying the system grew bigger day by day. 


\section{Final remarks}

Constructed wetlands have a large potential in developed and developing countries as robust, reliant and cost-effective wastewater treatment systems mutually addressing programmatic synergies with the social, spatial and environmental dimensions of urban development (Haberl, 1999; Zhang et al., 2009). From a technical point of view, the appropriateness of such systems has been thoroughly documented during the last 30 years (Kadlec and Wallace, 2009). Still, a rigorous desk top design and an appropriate set of safeguards do not eliminate the risk of system failure.

The risk of mistakes during construction works, the absence of adequate regulations and people awareness, the local history of past successes and failures, knowledge, practices and skills are all factors influencing the chances for long term sustainability. In a complex social setting with many stakeholders, motives and interests, as the one experienced at Koh Phi Phi, the continuous commitment and involvement of stakeholders and the shared and individual responsibility for the successful performance of the system is of paramount importance. At Koh Phi Phi the lack of a key person or a key authority taking responsibility for managing the system is regarded the most important reason that the system is not as successful as intended 3 years after implementation.

This circumstance points to the social and institutional dimension as the next crucial step to overcome in the task of developing a more sustainable wastewater management practice in developing countries. Hopefully, the positive and negative lessons learned from the planning, design, implementation and follow-up of the constructed wetland system at Koh Phi Phi can assist in doing so.

\section{Acknowledgements}

This is an elaborated version of a keynote paper presented at the Wetpol 2009 conference in Barcelona, Spain, 20-24 September 2009. We acknowledge the Danish Ministry of Foreign Affairs for financial support to establish the system.

\section{References}

APHA, 1998. Standard Methods for the Examination of Water and Wastewater. American Public Health Association, Washington, DC.
Brix, H., 1999. How 'green' are aquaculture, constructed wetlands and conventional wastewater treatment systems? Water Sci. Technol. 40, 45-50.

Brix, H., Arias, C.A., 2005. The use of vertical flow constructed wetlands for onsite treatment of domestic wastewater: New Danish guidelines. Ecol. Eng. 25, 491-500.

Brix, H., Koottatep, T., Laugesen, C.H., 2007. Wastewater treatment in tsunami affected areas of Thailand by constructed wetlands. Water Sci. Technol. 56, 69-74.

Brix, H., Schierup, H.-H., 1989. The use of aquatic macrophytes in water-pollution control. Ambio 18, 100-107.

Cooper, P., 2005. The performance of vertical flow constructed wetland systems with special reference to the significance of oxygen transfer and hydraulic loading rates. Water Sci. Technol. 51, 81-90.

Dreiseitl, H., Grau, D., 2009. Recent Waterscapes: Planning, Building and Designing with Water. Birkhäuser, Basel.

Haberl, R., 1999. Constructed wetlands: a chance to solve wastewater problems in developing countries. Water Sci. Technol. 40, 11-17.

Kadlec, R.H., Wallace, S.D., 2009. Treatment Wetlands. CRC Press, Boca Raton, FL.

Kantawanichkul, S., Kladprasert, S., Brix, H., 2009. Treatment of high-strength wastewater in tropical vertical flow constructed wetlands planted with Typha angustifolia and Cyperus involucratus. Ecol. Eng. 35, 238-247.

Konnerup, D., Koottatep, T., Brix, H., 2009. Treatment of domestic wastewater in tropical, subsurface flow constructed wetlands planted with Canna and Heliconia. Ecol. Eng. 35, 248-257.

Koottatep, T., Pongponrat, K., Taweesan, A., 2009. People's Participation in Wastewater Management in Tsunami Hit Area: A Case Study of Phi Phi Island. Southeast Asia Urban Environmental Management Applications Project, Final Report. Environmental Engineering and Management, Asian Institute of Technology, Thailand.

Koottatep, T., Surinkul, N., Polprasert, C., Kamal, A.S.M., Kone, D., Montangero, A., Heinss, U., Strauss, M., 2005. Treatment of septage in constructed wetlands in tropical climate: lessons learnt from seven years of operation. Water Sci. Technol. 51, 119-126.

Kouchi, K., Yamazaki, F., 2007. Characteristics of tsunami-affected areas in moderate-resolution satellite images. IEEE Trans. Geosci. Remote Sens. 45, 1650-1657.

Laugesen, C.H., Fryd, O., Koottatep, T., Brix, H., 2010. Sustainable Wastewater Management in Developing Countries: New Paradigms and Case Studies from the Field. American Society of Chemical Engineers Press, Reston, VA.

Papadopoulos, G.A., Caputo, R., McAdoo, B., Pavlides, S., Karastathis, V., Fokaefs, A., Orfanogiannaki, K., Valkaniotis, S., 2006. The large tsunami of 26 December 2004: field observations and eyewitnesses accounts from Sri Lanka, Maldives Is. and Thailand. Earth Planets Space 58, 233-241.

Rigg, J., Grundy-Warr, C., Law, L., Tan-Mullins, M., 2008. Grounding a natural disaster: Thailand and the 2004 tsunami. Asia Pac. Viewp. 49, 137-154.

Vymazal, J., Greenway, M., Tonderski, K., Brix, H., Mander, U., 2006. Constructed wetlands for wastewater treatment. Ecol. Stu. An. 190, 6996.

Zhang, D.Q., Gersberg, R.M., Keat, T.S., 2009. Constructed wetlands in China. Ecol. Eng. 35, 1367-1378.

Zurita, F., De Anda, J., Belmont, M.A., 2009. Treatment of domestic wastewater and production of commercial flowers in vertical and horizontal subsurface-flow constructed wetlands. Ecol. Eng. 35, 861-869. 